\title{
Land Ownership and Profitability of Greenhouse Production: Antalya Case
}

\author{
Rahmiye Figen Ceylan ${ }^{1 *}$, Cengiz Sayin ${ }^{1}$, Makbule Nisa Mencet Yelboğa ${ }^{1}$, \\ Meral Özalp ${ }^{2}$, Eda İlbasmişs ${ }^{3}$, Oya Sav ${ }^{3}$
}

${ }^{1}$ Department of Agricultural Economics, Faculty of Agriculture, Akdeniz University, 07070 Antalya, Turkey

${ }^{2}$ Department of Accounting, Kumluca Vocational College, Akdeniz. University, 07350 Antalya, Turkey

${ }^{3}$ Department of Agricultural Economics, Graduate School of Natural and Applied Sciences, Akdeniz University, 07070 Antalya, Turkey

A R T I C LE INFO

\section{Research Article}

Received 19 March 2018

Accepted 10 May 2018

\section{Keywords:}

Antalya

Greenhouse

Land ownership

Profit efficiency

Stochastic profit frontier

*Corresponding Author:

E-mail: ceylan.figen@gmail.com \begin{abstract}
A B S T R A C T
Agricultural production and income are important for Mediterranean region of Turkey. The region and especially Antalya province is well-known with greenhouse production. For greenhouse production achieving sustainability is important for meeting domestic and foreign demand and security of production lands. In order to measure the potential for improving greenhouse operators 281 farmers were surveyed in 2015 in Antalya and profit inefficiency and factors affecting inefficiencies of operators were estimated using stochastic frontier approach. Accordingly, the average inefficiency level of operators was found as $57 \%$, signifying the potential for improvement. The main objective was to undermine the impact of landownership on this inefficiency level. Yet, the impact of other relevant factors referring to greenhouse structures and famers' characteristics were estimated as well. While level of education seemed to reduce inefficiency, household size had appeared as an inefficiency rising factor referring to professional labour endowment of greenhouse production in Antalya. Being renter of land appeared as an inefficiency rising factor as well as holding plastic house or having located in the western parts of Antalya. These findings indicated importance of supporting improved production technologies and use of strengthened structures. In addition, it appeared as essential to provide incentives to renters to cope with their costs.
\end{abstract}

DOI: https://doi.org/10.24925/turjaf.v6i7.930-935.1921

\section{Introduction}

Economic activities are assessed with regards to their return on investment and costs. The profitability is measured towards sustainable management of costs for every sector respecting their specific features. Profit efficiency is an eligible tool for measurement of profitability, which can be achieved via full utilisation of inputs for goods and services production. An enterprise can be called as profit efficient if it is able to maximize its profits or cover its expenditures and reach a positive balance (Lau and Yotopoulos, 1971). Therefore, return on fixed and variable inputs provide us with the knowledge of profitability or profit efficiency for a given period of time (Rachmina et al., 2014; Kumbhakar and Lovell, 2000; Sadoulet and de Janvry, 1995). Profit efficiency can be measured after diversification of technical and allocative efficiency of production (Ali et al., 1994; Karafillis and Papanagiotou, 2009). Therefore, it was intended to measure profit efficiency of high value added greenhouse vegetable production in Antalya, Turkey and to interpret the reasoning.

Turkey is one of the net agricultural exporters in the world. Fresh fruits and vegetables (FFVs) is an important segment and Mediterranean province of Antalya has a significant share on production and exports of FFVs with endemic variety richness, poli-cultural production opportunities, potential to use developing technology, higher producer awareness and availability of transportation lines (Anonymous, 2012; Anonymous, 2013).

Due to TUIK data the total export value of "edible vegetables and certain roots and tubers' and 'edible fruits and nuts, peel of melons or citrus fruits' refers to almost 4.5 billion Dollars, and most of this value is retrieved from covered production. Covered production is considered in four sub-sectors. These are known as low tunnel, high tunnel, plastic and glass house systems. 80\% of glasshouse and $60 \%$ of greenhouse vegetable production takes place in Antalya with utilisation of 37\% of total available covered production land due to 2017 data as indicated in Table 1 (Anonymous, 2018).

Accordingly, the profit inefficiency of plastic/glasshouses was calculated via stochastic profit frontier approach for 281 enterprises using face-to-face survey data retrieved on 2015. Afterwards, effects of land ownership, land fragmentation and socio-demographic features of producers were estimated against calculated 
profit inefficiency of operators to sign the potential for improvement of profitability. The paper follows up with explanation of material and methodology and provision and evaluation of the findings.

Table 1 FFVs Amount Produced (1.000 tonnes) for Turkey and Antalya*

\begin{tabular}{l|ccc}
\hline \multicolumn{1}{c|}{ Production Mode } & Antalya & Turkey & $\%$ \\
\hline Low Tunnel & 43867 & 1092157 & 4.017 \\
High Tunnel & 47098 & 787980 & 5.977 \\
Glasshouse & 1056279 & 1315474 & 80.3 \\
Plastic house & 2454644 & 4157546 & 59.04 \\
TOTAL & 3601888 & 7353157 & 48.98 \\
\hline
\end{tabular}

*Anonymous, 2018

\section{Material and Methodology}

\section{Material}

The research was based upon a field survey conducted in three towns (Centre, Serik and Kumluca) of Antalya, which are widely known with greenhouse production. The targeted towns make significant contribution to fourseason FFVs supplies of Turkey and its trade partners and provide a more than average agricultural income to the producers.

After the sample was determined respecting random sampling (Yamane, 2001), 281 producers were surveyed in 2015 with $95 \%$ confidence interval. The stratification was made based on the number of operators and the sample results were demonstrated in Table 2. The number of producer based sample distribution was preferred as the estimation was made for $1000 \mathrm{~m}^{2}(0.1$ hectares $)$ of production land and the variation between enterprises was assumed to be based on quality rather than quantity (Norton, 1928).

Table 2 Population and Sample Information

\begin{tabular}{l|ccc}
\hline \multicolumn{1}{c|}{ Town } & Population & Sample & $\begin{array}{c}\text { Number of } \\
\text { surveys }\end{array}$ \\
\hline Antalya Centre & 1.500 & 35 & 43 \\
Kumluca & 10.000 & 185 & 183 \\
Serik & 3.000 & 55 & 55 \\
Total & 14.500 & 275 & 281 \\
\hline
\end{tabular}

\section{Methodology}

The main methodology incorporated was stochastic profit frontier approach in estimation of profit inefficiency of farms. Firstly, profit-cost structure of the farms was portrayed and unit costs incurred and revenue received was calculated per 0.1 hectares (Sidhu and Baanante, 1981; Chambers et al., 1998). Secondly, calculated gross profits of 281 farms were estimated against unit variable and fixed costs to find crosssectional profit inefficiency.

The stochastic frontier model was simultaneously proposed by Aigner et al. (1977) and Meeusen and Van den Broeck (1977) who drew their works upon the Farrell (1957). The methodology is based on productive efficiency measures referring producing the given amount at the minimum cost possible (Aigner et al., 1977; Meeusen and Van den Broeck, 1977; Kolawole, 2006). The variable costs as unit production costs and fixed costs as depreciation of physical capital, interest rates, administrative expenses (direct and indirect taxes) were incorporated in the estimating equation following Guan and his friends (2009).

The relationship of net farm income or gross profit was estimated referring to trans-logarithmic transformation profit function and the aim of the estimation was to retrieve profit inefficiencies of the operators. Accordingly, the main equation was as following.

$$
\ln \left(\pi_{i)}=f\left(V C_{i j}, F C_{i k}, A_{i}\right) \exp \left(e_{i}\right)\right.
$$

Here farm level gross profit for 0.1 hectares were estimated against variable and fixed costs incurred for production including amount of production land. The inputs used were fertilizer cost (TL/1000 $\left.\mathrm{m}^{2}\right)$, pesticide cost (TL/1000 $\left.\mathrm{m}^{2}\right)$, seedling cost (TL/1000 $\mathrm{m}^{2}$ ) and depreciation of greenhouse house machinery (TL) and amount of production land $\left(1000 \mathrm{~m}^{2}\right)$. Although the data retrieved was in Turkish Liras (TL), the findings were interpreted after Turkish Lira and Dollar conversion in order to enable international comparison.

In the second step of the research, the impact of relevant socio-demographic characteristics and land/tenure ownership on the profit inefficiency were analysed. The inefficiency indices ranging between 0 and 1 were retrieved from the error terms of profit function estimates.

Profit efficiency measurement refers to decomposition of technical and allocative inefficiency involved in the regression variation (Karafillis and Papanagiatou, 2009; Ali et al., 1994). The variation of the profit function's error terms is composed of random error and profit inefficiency and can be demonstrated as following (Batesse and Cora, 1977; Batesse and Coelli, 1993, Kolawole, 2006).

$$
\sigma^{2}=\sigma_{u}^{2}+\sigma_{v}^{2}
$$

The non-random inefficiency score was retrieved from the anti-log of the variation.

$$
K E I_{i}=\left(1-\mathrm{e}\left(-\mathrm{u}_{\mathrm{i}}\right)\right)
$$

Then, the impact of following factors on the inefficiency level was estimated via OLS modelling. The analysis was made with NLOGIT 5 statistical package.

$$
K E I_{i}=f\left(A_{i}, T_{i}, H_{i}, L_{i}, I_{i}, G_{i}\right)
$$

Where;

$\mathrm{KEI}_{\mathrm{i}}$ :Profit inefficiency index of the $\mathrm{i}^{\text {th }}$ enterprise

$T_{i}$ :Education level of the farmer in the $i^{\text {th }}$ enterprise

$\mathrm{H}_{\mathrm{i}} \quad$ :Number of households in the $\mathrm{i}^{\text {th }}$ enterprise

$\mathrm{L}_{\mathrm{i}}$ :Operator of the $\mathrm{i}^{\text {th }}$ enterprise being the landowner (0) or renter/cashcropper (1)

Ii :Dummy variables referring to the geographical location of the $i^{\text {th }}$ enterprise (Central town Kumluca- Serik)

$\mathrm{Gi}$ :Dummy variables referring whether the $\mathrm{i}^{\text {th }}$ enterprise is plastic or glasshouse 


\section{Findings}

\section{Socio-Demographic Findings}

So far, it was understood that the average age of the farmers involved was 42.68 . As $63 \%$ of the farmers were between 30 and 50, it is possible to note that greenhouse production has been maintained by the middle age group. Again $63 \%$ of farmers had primary education degrees with 8 years, while only 14 farmers out of 281 were holding Bachelor's degree. Almost all of the farms were family farms.

While there was multi-crop production in many farms, mostly produced crops were tomato (150 enterprises) and fresh pepper (green and red) (113 enterprises). The production facility distribution was as expected with $24 \%$ (75) glasshouses and 76\% (244) plastic houses.

When structures were considered, it was understood that there were 144 unified greenhouses and 137 enterprises were composed of more than one piece. The average land occupied was 0.45 hectares and there was a pieced structure that average number of pieces was 2 . In addition, average age of the plastic/glasshouses was 13.5 and most of the producers had more than 10 years of experience. The average value of green/glasshouse field was 25901.82 Dollars. In addition, average monthly rent of the operators was 1252.25 Dollars (Respecting 1 Dollar=3.8068 TL as of 04.03.2018 - applied to all financial data).

Average amount produced was 35 tonnes for 281 producers irrespective of occupied land. The average yearly gross income was 14309.53 Dollars and it was 37.9 Dollars per $1000 \mathrm{~m}^{2}$. The average total variable cost for these farms was 7021.73 Dollars, while it was 19.0 Dollars per $1000 \mathrm{~m}^{2}$. Therefore, gross profit for 0.1 hectare was 18.9 Dollars for the concerned greenhouses. These cost and profit figures refer to almost $50 \%$ profitability. The average farm level gross profit was 7288.8 Dollars. The highest profit level was observed in Central town with 8149 Dollars, while the lowest was in Kumluca with 5661 Dollars on farm level. This variation could be explained by the widespread plastic house production in Kumluca, which is less endurable to climatic variations. In addition, ease to reach domestic and export markets from the Centre, is another factor leading higher profits.

Considering this economic outlay, it is important to diversify the gross profit with regards to inputs utilised and check for the relationship between profit efficiency and greenhouse ownership and structure in addition to socio-economic indicators.

\section{Stochastic Profit Frontier}

The gross profit was estimated with stochastic profit frontier approach prior to in depth analysis of the inefficiency. Yet, it is first important to note that the dependent variable was used after logarithmic transformation due to the Likelihood Ratio test results $(\mathrm{LR}=55)$. The estimation results indicated that all cost indicators affect the gross profit and estimates have both single and joint significance (Table 3 ).

Even if the major objective of the research was to retrieve inefficiencies of greenhouse farms, all cost figures were assumed to contribute gross profit positively including the amount of land and pre-determined costs for 0.1 hectares. Therefore, higher scales of production, which is widespread in the region, seemed to enable higher profitability of the farms due to increasing returns to scale expectations.

Afterwards, the profit inefficiencies of farms were computed using the variation of estimation error. It was understood that more than half of farmers were inefficient with an average inefficiency level of $57 \%$. The inefficiencies of covered production units were between 7 and $87 \%$. This high level of average inefficiency signed that there is a possibility to increase efficiency of farms. However, which policy tools can be used for manipulating the efficiency can only be understood after the reasoning of the inefficiency was analysed.

Accordingly, the relationship between ownership status of the greenhouse, socio-demographic features of the farmer and location of the plastic/glass house was estimated. The inefficiency index retrieved was estimated against personal and productive characteristics of the operator of target greenhouse farms (Table 4).

Table 3 Stochastic Profit Frontier Estimation

\begin{tabular}{l|cc|c|c}
\hline \multicolumn{1}{c|}{$\ln \left(\pi_{i}\right)$} & Estimate & Std. Dev. & $\mathrm{z}$ & $>\mathrm{Z}^{*}$ \\
\hline Constant & 5 & 0.659 & 30.35 \\
$\mathrm{~A}_{\mathrm{i}}$ & $2.46^{* * *}$ & 0.103 & 21.8 \\
$\mathrm{G}_{\mathrm{i}}$ & $0.005^{* * *}$ & $7 \mathrm{E}-04$ & 6.63 \\
$\mathrm{~F}_{\mathrm{i}}$ & $0.0006^{* * *}$ & 0.002 & 4.14 \\
$\mathrm{~K}_{\mathrm{i}}$ & $2.07 * * *$ & 0.004 & 8.91 \\
$\mathrm{D}_{\mathrm{i}}$ & $0.01 * * *$ & $3 \mathrm{E}-04$ & 4.28 \\
\hline \multirow{2}{*}{}
\end{tabular}

Table 4 Inefficiency Estimates

\begin{tabular}{l|ll}
\hline \multicolumn{1}{c|}{ KEI } & Estimate & \multicolumn{1}{c}{ t-stat } \\
\hline Constant & 0.636 & $8.765^{* * *}$ \\
$\mathrm{~T}$ - Education Level & -0.15 & $1.778^{*}$ \\
$\mathrm{H}$ - Household Size & 0.011 & $2.105^{* *}$ \\
$\mathrm{~L}$ - Operator is renter & 0.017 & $2.03^{*}$ \\
$\mathrm{I}_{\mathrm{K}}$ - Operator is located in Kumluca & 0.022 & 1.39 \\
$\mathrm{I}_{\mathrm{S}}$ - Operator is located in Serik & -0.21 & 1.72 \\
$\mathrm{G}_{\mathrm{g}}$ : Glasshouse & -0.24 & $1.861^{*}$ \\
$\mathrm{G}_{\mathrm{p}}$ : Plastic house & 0.021 & 1.42 \\
\hline
\end{tabular}

* significant with $90 \%$; ** significant with $95 \%$; *** significant with $99 \%$

The estimated average inefficiency level of 281 operators was $63 \%$, looking at the constant of the estimation, when all other factors were kept apart. Considering the average calculated inefficiency of $57 \%$, the categorical variables used to have an impact over the inefficiency.

There found both inefficiency rising and reducing factors. Specifically, the factors that were reducing the average inefficiency were operator having located in Serik town of Antalya and making production in glasshouses as well as the education level of the producer. While, plastic house production seemed to increase inefficiency by $2.1 \%$, the potential of reducing inefficiency with utilisation of glasshouses was found as $24 \%$ on average. It needs to be noted that two structural dummies were incorporated in the regression 
simultaneously as there were farmers with both plastic and glasshouses. Therefore, the possibility for overestimation did not take place for the concerned estimation.

Household size had a rising effect on the inefficiency with $1.1 \%$. Despite being significant with $95 \%$, this finding can be attributed to lower contribution of family labour and professionalization of greenhouse production. Yet, higher education level was found as an inefficiency reducing factor, confirming the expectations. However, the low number of producers having tertiary graduation degree, disabled us to draw a general conclusion. Most of the greenhouse operators were traditionally involved in agricultural production and got used to system modifications in time. So, experiences cannot be completely neglected.

Location of the greenhouse also appeared as an effective factor. For operators taking place in Kumluca town, which is the widest greenhouse production centre of Antalya, inefficiency seemed to increase. This can also be attributed to saturation level of the town and declining yields due to overuse of lands (Yilmaz et al., 2010). Despite, producers in eastern Antalya - Serik seemed to demonstrate lower inefficiencies. Yet, it is important that the single significances of these location dummies were considerably low.

Finally, the factor referring to ownership needs to be interpreted. Producers who were renters of the greenhouse or its land faced with rising inefficiency with $90 \%$ significance. This can be read as the owners occupy a better position with respect to profitability. Besides, average on-season monthly rent rates of 1252.25 Dollars had a rising affect over costs of operators.

Finally, even there were insignificant categorical estimates, it can be noted that overall significance of the estimates was considerably high with 35.90 F-statistic. Accordingly, the interpretation of the analysis can be concluded as the factors focused explain the inefficiency levels of greenhouse operators by $48 \%$.

\section{Results and Discussion}

Covered production systems are widely acknowledged for Mediterranean region of Turkey with its high contribution to agricultural production and trade income. Yet, especially in Antalya, it is being observed that greenhouse production has almost reached a saturation level and relevant policies need to be used for fostering yields. In order to undermine the possibilities to increase contribution of plastic/glasshouse vegetable production to national income as well as farm level income, measuring the efficiency of farm operators appeared as essential. Accordingly, stochastic profit frontier approach was utilised to understand the inefficiency of greenhouse FFVs production in centre, east and west of Antalya, Turkey. A face to face survey was conducted with 281 plastic/glasshouse vegetable producers in 2015.

Due to the primary data retrieved, it was understood that very few farmers were operating relatively with efficiency as only $20 \%$ of producers had inefficiency score below 0.3. Besides, aging structures of greenhouses were considered as effective. The losses born by greenhouse holders in west Antalya after a tornado that took place in 2015 was around 5 million Dollars and subsequent tornados in 2015 and 2016 leaded major loses for greenhouse farmers in the region (Ersoy, 2015-2016). These figures signify the impact of the structures.

Maintaining agricultural production for Turkey, as well as for other countries with high agricultural production capacities, has three main objectives. These are increasing agricultural income and its contribution to national income, meeting agricultural and food demand of nationals domestically and keeping farmers on their lands both to secure agricultural lands and prevent migration to urban districts. Accordingly, increasing profits with minimising costs rather than overusing the available environmental holdings is an important concern. With this respect, the inefficiency reasoning for plastic/glass house production was estimated and the findings confirmed main economic and social expectations.

Specifically, education level of farmers could be considered as an inefficiency reducing factor, despite the fact that there were a limited number of producers with higher education degrees. However, providing more extension information and professional supports should be considered for sustainability of greenhouse production and trade. In addition, while plastic houses, with a high depreciation potential, seemed to increase inefficiency of the operator, glasshouse operations seemed to reduce it. Accordingly, conversion to glasshouses and developing supportive policies for structural improvement could be effective. Yet, the locational impact showed that overuse of land and other environmental assets would constitute a barrier in the future, even if it is not a problem apparently. Therefore, awareness raising activities for chemical use becomes a prevalent option for sustainability.

There have been different studies focused on determination of reasons behind agricultural profit inefficiency. A reference study focusing on government controlled and free market price influences on farmer profitability in China revealed that farmer's education and resource endowments affect efficiency (Wang et al., 1996). Therefore, determined educational impact, which should be related with extension activities as well, confirms with these findings.

Total factor productivity declination in Russian farms and the reasoning behind were analysed within a panel structure between 1996 and 1998 (Bezlepkina, 2002). The findings indicated that budget transfers to farms have inverse effects on productivity of crop and animal producing farms and result in extensive taxation. Yet, favourable weather conditions and rising domestic demand used increase farm outputs. Even if this study has focused on domestic production, the impact of rising demand can also be considered as a confirmation of selfsufficient FFVs production in Turkey that is induced by foreign demand. Factors affecting Nigerian small scale rice farmers' efficiency were estimated by Kolawole (2006). It was understood that efficiency in subsistence level rice farming was affected positively by age, education level and experience of the farmer and household size positively. Therefore, farmer's characteristics appeared as more significant in small scale farming. Considering the professionalization of greenhouse production in Antalya, significance of macroeconomic factors is understandable. 
Hazelnut farmers in Turkey were found as inefficient with 38 and $19 \%$ depending on the area based stratification and socio-demographics was found effective on this inefficiency (Aktas et al., 2011). In another study conducted to differentiate inefficiency levels of greenhouse tomato production seasons in Antalya, it was found out that there are significant inefficiency differences. The inefficiency rates for autumn, summer and winter seasons were 16, 21 and $17 \%$ and the reasoning was climatic conditions (Ozkan et al., 2011). Even though our study did not differentiate between crops and production seasons, the higher inefficiency estimates seemed to support our environmental concerns regarding overuse of greenhouse lands.

One of the specialities that this study intended to measure was the impact of land or infrastructure (plastic/glass house) ownership. The findings of the estimation revealed that, with high average rents incurred for the operators with 1252.25 Dollars for lands or greenhouses, being a renter seemed to increase inefficiency. Therefore, providing incentives for landownership or adjusting a fair sharecropping system can be considered as a potential field for efficiency raising. As landowners cannot be forced to hand their lands over, providing financial incentives that are not attached to production amount should be considered as possible supportive actions. This suggestion is also compatible with development of supporting tools that will not intervene in trade advantages of the operators due to WTO requirements.

To summarise, it should be inferred that value added from plastic/glass house production in the Mediterranean region should be increased and sustained for meeting objectives of agricultural policies. The field survey conducted in three towns of Antalya with 281 operators signified the need for further information and better technology incorporation. Referring to the main objective of the study, ownership of the occupied land/facility is an important factor to affect efficiencies of producers and will be more important in the future. Accordingly, tools to support land ownership should be developed and incorporated in order to achieve sustainability of greenhouse production with higher yields and reducing environmental costs.

\section{Acknowledgement}

The paper is based on the project report entitled 'Tagem-14/Arge/63 Taxation in Agricultural Markets And Effects Of Taxation On Price Formation: Example From Antalya Greenhouse Production' funded under Research and Development Program of General Directorate of Agricultural Research and Policies of Ministry of Food, Agriculture and Animal Breeding in Turkey - TAGEM.

\section{References}

Aigner DJ, Lovell CAK, Schmidt P. 1977. Formulation and Estimation of stochastic frontier production models. Journal of Econometrics. 6:21-32.

Aktas AR, Ozturk E, Hatirli SA. 2011. Analysis of Profit Inefficiencies in Turkish Hazelnut Agriculture. Journal of Agricultural Sciences. 17:230-240.
Ali F, Parikh A, Shah MK. 1994. Measurement of Profit Efficiency Using Behavioural and Stochastic Differences in Frontier Approaches. Applied Economics. 26(2): 181-88.

Anonymous. 2012. Antalya Provincial Directorate of Food, Agriculture and Animal Breeding. Strategic Plan for Antalya Agriculture. Antalya. 2012-2016: 47-68.

Anonymous. 2013. Antalya Provincial Directorate of Food, Agriculture and Animal Breeding Agricultural Investment Manual for Antalya, http://www.tarim.gov.tr/SGB/ TARYAT/Belgeler/guncellenmesigererkenilyatirim/antalya. docx

Anonymous. 2018. TUIK data retrieved from https://biruni.tuik.gov.tr/medas/?kn=92\&locale $=\mathrm{tr} \quad$ on 02.03.2018

Battese GE, Coelli TJ. 1995. A Model for Technical Inefficiency Effect in Stochastic Frontier Production for Panel Data. Empirical Economics. 20, 325-345.

Battese GE, Corra GS. 1977. Estimation of a Production Function Model with Applied to the Pastoral Zone of Eastern Australia. Australian Journal of Agricultural Economics. 21, 169-179. https://doi.org/10.1111/j.14678489.1977.tb00204.x

Bezlepkina IV. 2002. What is Behind the Fall in Russian Agricultural Production? The $\mathrm{X}^{\text {th }}$ EAAE Congress Exploring Diversity in the European Agri -Food System, Zaragoza (Spain), 28-31 August 2002.

Chambers RG, Chung Y, Färe R. 1998. Profit, Directional Distance Functions, and Nerlovian Efficiency. Journal of Optimization Theory and Applications. 98-351. https://doi.org/10.1023/A:1022637501082

Ersoy S. 2015. 2015 Y1lının Doğa Kaynaklı Afetleri "Dünya ve Türkiye" - Natural Disasters of 2015 "the World and Turkey". Chamber of Geology Engineers Publication. Ankara. ISBN: 978-605-01-0854-5. http://www.jmo.org.tr/ resimler/ekler/cb5590ed725b536_ek.pdf

Ersoy S. 2016. 2016 Y1lı Doğa Kaynaklı Afetler Yıllığı "Dünya ve Türkiye" - 2016 Yearbook of Natural Disasters"the World and Turkey". Chamber of Geology Engineers Publication. Ankara. ISBN: 978-605-01-1005-0. http://www.jmo.org.tr/resimler/ekler/9c6533fe59fd883_ek.p df

Farrell MJ. 1957. The measurement of productive efficiency. Journal of the Royal Statistical Society. 120/ 253-290.

Guan Z, Kumbhakar SC, Myers RJ, Lansink AO. 2009. Measuring Excess. Capital Capacity in Agricultural Production. American Journal of Agricultural Economic. 91(3): 765-776.

Karafillis C, Papanagiotou E. 2009. Innovation and Profit Efficiency in Organic Farming. World Journal of Agricultural Sciences. 5 (1): 74-82.

Kolawole O. 2006. Determinants of Profit Efficiency among Small Scale Rice Farmers in Nigeria: A Profit Function Approach. Poster paper prepared for presentation at the International Association of Agricultural Economists Conference. Gold Coast, Australia. August 12-18, 2006. Retrieved from: http://ageconsearch.umn.edu/bitstream /25238/1/pp060688.pdf

Kumbhakar C, Lovell CAK. 2000. Stochastic Frontier Analysis. Cambridge University Press. ISBN: 0-521-48184-8.

Lau LJ, Yotopoulos PA. 1971. A Test for Relative Efficiency and Application to Indian Agriculture. The American Economic Review. 61(1): 94-109.

Meeusen W, Julien VDB. 1997. Efficiency Estimation from Cobb- Douglas Production Functions with Composed Error. International Economic Review. 18:435-444.

Norton LJ. 1928. Average Variations in Yields, Acreage and Production. Journal of the American Statistical Association. 23(161): 61-63. 
Ozkan, B, Hatirli, SA, Ozturk E, Aktas A. 2011. Antalya İlinde Serada Domates Üretiminin Kâr Etkinliği Analizi. Tarım Bilimleri Dergisi- Journal of Agricultural Sciences 17(2011) 1-8.

Rachmina D, Daryanto A, Tambunan M, Budiman HD. 2014 Impact of infrastructure on profit efficiency of vegetable farming in West Java, Indonesia: Stochastic frontier approach. Journal of the International Society for Southeast Asian Agricultural Sciences. 20(1):77-92.

Sadoulet E, Janvry A. 1995. Quantitative Development Policy Analysis. Baltimore. The Johns Hopkins University Press.

Sidhu S, Baanante C. 1981. Estimating Farm-Level Input Demand and Wheat Supply in the Indian Punjab Using a Translog Profit Function. American Journal of Agricultural Economics. 63: 237-246. https://doi.org/10.2307/1239559
Yamane T. 2001. In A. Esin, M. Akif Bakır, \& C. A. ve E. Gürbüzsel (Trans.), Temel Örnekleme Yöntemleri -Main Methods of Sampling (Birinci Bask1, 1st issue). İstanbul, TR: Literatür Yayıncilik.

Yilmaz I, Sayin C, Ozkan B. 2010. Turkish Greenhouse Industry: Past, Present, and Future. New Zealand Journal of Crop and Horticultural Science. 33(3):233-240. DOI: 10.1080/01140671.2005.9514355

Wang J, Wailes EJ, Cramer GL. 1996. A Shadow-Price Frontier Measurement of Profit Efficiency in Chinese Agriculture. American Journal of Agricultural Economics. 78 /146156. https://doi.org/10.2307/1243786. 